Relations industrielles

Industrial Relations

\title{
Recreation and Labour Relations
}

\section{Louise Dumais}

Volume 4, numéro 3, novembre 1948

URI : https://id.erudit.org/iderudit/1023450ar

DOI : https://doi.org/10.7202/1023450ar

Aller au sommaire du numéro

Éditeur(s)

Département des relations industrielles de l'Université Laval

ISSN

0034-379X (imprimé)

1703-8138 (numérique)

Découvrir la revue

Citer cet article

Dumais, L. (1948). Recreation and Labour Relations. Relations industrielles / Industrial Relations, 4(3), 27-29. https://doi.org/10.7202/1023450ar

Tous droits réservés @ C Département des relations industrielles de l’Université Laval, 1948
Ce document est protégé par la loi sur le droit d'auteur. L'utilisation des services d'Érudit (y compris la reproduction) est assujettie à sa politique d'utilisation que vous pouvez consulter en ligne.

https://apropos.erudit.org/fr/usagers/politique-dutilisation/ 


\section{RECREATION AND LABOUR RELATIONS}

Louise DumaIs

The problem of recreation is one of the questions of the day. It interests not only men of action but also thinkers, because of the particular place occupied in the life of modern man by leisure as opposed to work. In considering the worker, we have to admit that his life is not at all what it was even ten or eleven years ago. A sharp distinction has been drawn between his leisure and his working hours.

It was not always so. The social upheavals which followed the advent of industrialism, at first placed the worker in an extremely distressing position because of the long duration of his work and the poor conditions under which that work was accomplished - bad ventilation of buildings, insufficient time off for meals, too much handling of heavy implements etc. These unfavourable conditions and the long hours of work produced consequences of intense impoverishment and were, at time, even fatal. It was then, at the turn of the century, that worker's associations and national and international organizations intervened to try and establish a rigorous legislation concerning day labour.

Formerly the worker toiled each day, twelve or fifteen hours and sometimes longer, without even having the right, in certain countries, to a weekly day of rest. Nowadays, he can regulate his own time after having worked the eight or ten hours necessary to gain his daily bread and that of his family. Some countries have even introduced the five-day week, and almost everywhere in the world, the labourer as well as the employee of the office and shop, benifits from vacations with pay. Such legislation permits us to estimate that in the United States the present-day worker enjoys about four thousand hours of leisure in the year. The Canadian worker, for his part, has at his disposal about 3,500 hours - already quite an appreciable amount.

And we can visualize further gains if we consider the problem of the needs of man and the neverceasing progress resulting from the new techniques of production. Certain economists go so far as to forecast that a better co-ordination of the services of production in function with the evaluation of human needs, will lead eventually to the gradual reduction of work to some hours each day or even each week. One has only to observe the ground gained during the last hundred years in technical perfection, to conclude that such a perspective of shortened labour is not at all absurd.

The constant reduction in working hours which has followed the excesses prevalent at the beginning of the industrial era, has contributed to the separation of the notions of «leisure » and «work». Leisure is born of the nature of the work which man accomplishes, and from the conditions under which he practises his trade or his profession.

We can give it the following definition: Leisure is the time which man can dispose of freely after having satisfied by his work the obligation to gain his livelihood and that of his family. It is the time when he is free from the restraints of work... Yet, this freedom tends to diminish as man takes further part in community living which obviously demands a certain order even in leisure time. Thus, every individual is free to participate or not in certain group games, but the minute that he does participate he must observe the rules.

Taken in itself, leisure has clearly a positive meaning whether it be expressed in action or in repose. It is naturally exercised only in the waking state since sleep prevents the expression of free will. It has for object to contribute to the broadening of human personality through the development of a harmonious equilibrium of body and mind. After the effort occasioned by work, leisure offers itself as either an impulse of action or an impulse of relaxation. But we must be careful in comparing it with idleness or inertia or again with restlessness because these are negative and sterile states and only caricatures of leisure. Also, we must be cautious when it comes to standardized organizations and to regimented recreational services, because these may limit the normal development of the personality.

Leisure, or recreation, responds to a legitimate need of man, and since each legitimate need corresponds to a right, leisure should be considered as an object of law. The actual ordering of our economic and social life, by dividing work and leisure, has bestowed on each a role carrying with it obligations and privileges and aiming at the attainment of a full and complete existence for everyone. 
So man, while needing to work, needs also recreation. Original sin assigned to man his laborious role. Therefore the human being must commence by seeking himself the answer to his primary needs such as food, clothing and shelter. In the course of the centuries, the neverceasing improvement in his inventions has allowed him, little by little, to free himself of certain servitudes while levaing with him the need and desire to strive for perfection.

Every man has a right to recreation as he has a right to work. $\mathrm{He}$ is not a machine, but, even if he were he would be given the necessary care and an opportunity to rest. As man, he leads the life of a human being with all that that implies. After work, he has the right to profit from his free time according to his tastes and aptitudes while, of course, conforming to ethical standards; he has the right to round off his education and culture; and he should also have the opportunity to fulfil his family, social and religious obligations.

The right to leisure time can not be considered as the privilege of only an elite or of one particular class. The more the day's work has been heavy and monotonous the more the time reserved for recreation should bring compensation and enrichment to the personality. The type of leisure then should be determined by the nature of each individual's occupation.

The employee who accomplishes an « anonymous » task cannot derive much pride or satisfaction from his iabour. From this point of view, the work of the artisan offers possibilities very much richer than does the piece-work of some labourers. The craftsman who carves a piece of furniture and the weaver, who after designing her patterns brings them into being on her loom, can be proud of their handiwork. These are joys which are known to very few in modern industry. A lack whose importance cannot be overestimated ! ${ }^{1}$

This lack is one of the evils whcih has come to us with progress. It prevails not only among factory hands but also among certain categories of out-door workers and of office and commercial employees. The best means of decreasing this disability, if not of making it disappear altogether, is to capture the interest of the workers in the complete process of production by explaining how

(1) Quite evidently, this does not mean the turning of our backs on industrialisation and the doing away of the machines which perform the larger part of the work leaving to man only the role of control. But, we must study carefully the fact that human values are left largely unemployed by the demands of modern labour and strive to find a propitious territory for their development. the activity of each is integrated in the final plan, and by arousing a spirit of willing collaboration. A liking for their work will naturally folow among those who become aware of their social and community role. It is thus important to create a «mystical» attitude towards work in order to permit the full development of the worker.

The difficulties which modern labour present should not make us neglect the importance of a wise use of leisure. For, however astonishing the paradox may seem, the fact remains that after having learned to work man must learn to make good use of his spare time. In this field, as in all others, he must acquire sensible habits if he would really be a free man.

It is noticeable that leisure time activities have their effect on the individual and on the quality of his work. What he does with his free hours determines whether his work seems heavy or light, sad or joyous.

Leisure, healthily employed, helps to sublimate the instincts. It is a rampart against the pernicious influences of certain environments. It applies a balm to the inevitable disappointments of life. Finally, it contributes to "recreate» the entire being because it is a balancing factor after the fatigue of labour.

Work, for its part, bears in such a marked way the impress of man, that all the influences acting on him rebound on his working activity and help determine its value.

If, because of human nature or the influence of environment or the poor quality of the recreation offered or again the difficult circumstances of his life, a worker's leisure hours are lessened, how can he bring to his work a strong and clearsighted mind? As a result it seems to us quite credible that so many employers need to complain of the inattention and the irresponsibility of their employees. An inquiry in to their leisure time activities would explain in a great part, their lack of enthusiasm and their dissatisfaction with their work.

Certain employers are completely disinterested in the behaviour of their workers once these have left the portals of the factory or the office. But, if these same workers, because of physiological fatigue and a pronounced intellectual impoverishment occasioned by a routine job accomplished under defective sanitary conditions cannot draw from their leisure all that sense of regeneration and enrichment which it should give, will they not be tempted to place on the employers the 
responsibility for their boredom, their fatigue and their mis-conduct? There is a problem that demands our attention if we do not wish some day or other, to face the forces of inaction or of revolt.

Recent experiments in the United States * reveal, in no uncertain fashion, that some jobs, because of the materials used, or of the position of the body during work, or again because of apparantly insignificant circumstances, leave more or less enduring traces on even the most robust organisms and call for particular forms of recreation in order to maintain and improve the health of the worker. Certain American industrialists put up with the incessant strikes of their employees for a long time. They finally had the idea of seeking the services of psychologists and medical men in order to discover the cause of the troubles. The research of these specialists revealed that the workmen's state of health was gravely deficient and was at the root of the general discontent.

They called in a specialist in recreation who organized regular meetings in physical education and demonstrated so well its attractions and advantages that all the workers hastened to take part. Then he organized with equal success games and sports in the open air, week-end excursions to the mountains, vacation camps for the young unmarried workers as well as for those with families. He even initiated folk-lore festivals and started a choir and play groups. The employees, with one stroke, improved the quality of their work, were re-made physically and learned to appreciate each other by sharing together the joys of nature and the healthy pleasures of sport and the arts.

Do not let us delude ourselves. We have an enormous task of education to accomplish which will demand the understanding of all — employers and employees, directors of personnel, labour leaders and those interested in community movements. In the case of the heads of industries, this comprehension should be shown in a indirect fashion to avoid giving rise to the reproaches of paternalism or of regimentation which we hear sometimes from the mouths of certain workers. Because the employee, often seeing only one aspect of his immediate welfare, will prefer to benefit from a raise in salary rather than to see offered (or sometimes imposed by the authorities), recreational facilities which he himself has not asked for.

(2) Report of Industrial Recreation Conference, New York City, 1947.
He is adult, and he intends to employ his spare time as seems good to him. This is his right. $\mathrm{He}$ cannot yet desire what he does not know or what he understands very poorly although he may sense an unconscious need. For example, the worker needs his own kind of culture just as much as the son of a professional man needs his. He suffers sometimes openly from an inferiority complex in this field. And as leisure time much more than working time leads to the flowering of the human personality, the petty employee does better to follow this cultural path and the more he is aided, instructed and guided the further he will go.

We live in a mechanical age whose accelerated production imposes obligations and bonds unknown to our ancestors. On the other hand, our century, so rich in contrasts, gives to employers and employees the privilege of collaborating efficiently in the coming advent of a real humanism destined to overcome proletarianism.

In the domain of recreation as in all other fields what merits being done, merits being done well. The conclusive experiments accomplished in the United States and in other industrialized countries can on occasion serve us as an example. It has been discovered that recreation to be a broadening factor, gains from being guided by social group workers. These technicians in recreation, studying together, are able to work out with individuals and groups the activities which best respond to the nature of their needs, their aptitudes, their tastes, and their social and matrimonial status. Thus, leisure, by way of consequence, may be a factor of intensified production and of social peace.

\footnotetext{
N.B.-The abundance of material submitted in the last few months has necessitated the postponement of the publication of this important text.
}

INDEX OF QUEBEC'S PRODUCTS AND MANUFACTURERS (1948): The seventh annual edition of this bilingual publication hàs just appeared. This review endeavours to make known the various products manufactured in the Province of Quebec and to create new commercial contacts on the Canadian market and abroad. Besides giving precise information on the economic activities of the Province, the Index illustrates, with the help of well presented statistics, Quebec's important share in the economic development of Canada as a whole.

This industrial directory should be of interest to every business man and is obtainable from "Les Editions du Commerce Inc.", 79 Boulevard Charest, Québec. 